\title{
Why doesn't conventional IVF work in the horse? The equine oviduct as a microenvironment for capacitation/fertilization
}

\author{
Bart Leemans ${ }^{1}$, Bart M Gadella ${ }^{2,3}$, Tom A E Stout ${ }^{2,4}$, Catharina De Schauwer ${ }^{1}$, Hilde Nelis ${ }^{1}$, \\ Maarten Hoogewijs ${ }^{1}$ and Ann Van Soom ${ }^{1}$ \\ ${ }^{1}$ Department of Reproduction, Obstetrics and Herd Health, Faculty of Veterinary Medicine, Ghent University, \\ Merelbeke, Belgium, ${ }^{2}$ Departments of Farm Animal Health, ${ }^{3}$ Biochemistry and Cell Biology and ${ }^{4}$ Equine Sciences, \\ Faculty of Veterinary Medicine, Utrecht University, Utrecht, The Netherlands
}

Correspondence should be addressed to B Leemans; Email: baleeman.leemans@ugent.be

\begin{abstract}
In contrast to man and many other mammalian species, conventional in vitro fertilization (IVF) with horse gametes is not reliably successful. The apparent inability of stallion spermatozoa to penetrate the zona pellucida in vitro is most likely due to incomplete activation of spermatozoa (capacitation) because of inadequate capacitating or fertilizing media. In vivo, the oviduct and its secretions provide a microenvironment that does reliably support and regulate interaction between the gametes. This review focuses on equine sperm-oviduct interaction. Equine sperm-oviduct binding appears to be more complex than the presumed species-specific calcium-dependent lectin binding phenomenon; unfortunately, the nature of the interaction is not understood. Various capacitationrelated events are induced to regulate sperm release from the oviduct epithelium and most data suggest that exposure to oviduct secretions triggers sperm capacitation in vivo. However, only limited information is available about equine oviduct secreted factors, and few have been identified. Another aspect of equine oviduct physiology relevant to capacitation is acid-base balance. In vitro, it has been demonstrated that stallion spermatozoa show tail-associated protein tyrosine phosphorylation after binding to oviduct epithelial cells containing alkaline secretory granules. In response to alkaline follicular fluid preparations (pH 7.9), stallion spermatozoa also show tail-associated protein tyrosine phosphorylation, hyperactivated motility and (limited) release from oviduct epithelial binding. However, these 'capacitating conditions' are not able to induce the acrosome reaction and fertilization. In conclusion, developing a defined capacitating medium to support successful equine IVF will depend on identifying as yet uncharacterized capacitation triggers present in the oviduct.

Reproduction (2016) 152 R233-R245
\end{abstract}

\section{Introduction}

Conventional in vitro fertilization (IVF) involves the penetration of a mature oocyte by a capacitated spermatozoon. The birth of Louise Brown in 1978 heralded the first successful conventional human IVF procedure in clinical practice (Steptoe \& Edwards 1978) and today, IVF is a well-established assisted reproductive technique in human medicine. In farm animals, conventional IVF has also become widespread, as illustrated by the 9930 IVF calves recorded to have been born in 2012, that is, $6.8 \%$ of all births (Perry 2013). Similarly, in pigs and various laboratory animals, dozens of offspring are produced by conventional IVF each year (Galli et al. 2003, Betteridge 2006). By contrast, despite the birth of two IVF foals in 1991 following incubation of oocytes with calcium ionophore treated spermatozoa (Palmer et al. 1991, Bézard et al. 1992), no reliable IVF protocol has yet been established for equine gametes (Choi et al. 1994, Dell'Aquila et al. 1997a,b, Alm et al.
2001, Hinrichs et al. 2002, Mugnier et al. 2009a). An overview of the published equine IVF studies is shown in Table 1, which illustrates the disappointing success rates, varying on an average between $0 \%$ and $33 \%$. Using calcium ionophore A23187 (Li et al. 1995, Alm et al. 2001), heparin (Li et al. 1995, Alm et al. 2001), zona pellucida proteins (Graham 1996), caffeine (Graham 1996), lysophospholipids (Graham 1996) and progesterone (Tremoleda et al. 2003), to trigger sperm activation, reported fertilization rates are very low. On the other hand, it has been demonstrated that both zona pellucida drilling and partial removal of the zona pellucida improve sperm penetration rates (Choi et al. 1994, Li et al. 1995, Dell'aquila et al. 1996), although the associated high rates of polyspermy render these approaches unusable in practice.

In 2009, McPartlin et al. reported very promising fertilization/cleavage rates (61\%) after co-incubating equine oocytes with stallion spermatozoa treated with 
R234 B Leemans and others

Table 1 Overview of equine conventional IVF results.

\begin{tabular}{|c|c|c|c|c|c|}
\hline $\begin{array}{l}\text { Oocyte } \\
\text { maturation }\end{array}$ & No. of oocytes & Sperm treatment & $\begin{array}{c}\% \text { fertilized oocytes with } 2 \\
\text { pronuclei }\end{array}$ & $\%$ cleaved oocytes & Reference \\
\hline In vivo & 113 & Ca lonophore A23187 & $14^{\mathrm{a}}$ & & Palmer et al. (1991) \\
\hline In vivo & 173 & Ca lonophore A23188 & $17^{\mathrm{a}}$ & $13^{\mathrm{a}}$ & Bézard et al. (1992) \\
\hline In vitro & 57 & $\begin{array}{l}\text { Caffeine/Ca lonophore } \\
\text { A23187 }\end{array}$ & 4 & & Choi et al. (1994) \\
\hline In vitro & 232 & Heparin & $12-33^{*}$ & $0-1 *$ & Dell'aquila et al. (1996) \\
\hline In vitro & 206 & Heparin & $4-17^{*}$ & 0 & $\begin{array}{l}\text { Dell'Aquila et al. } \\
\quad(1997 a)\end{array}$ \\
\hline In vitro & 203 & Heparin & $6-8^{*}$ & $2-3^{*}$ & $\begin{array}{l}\text { Dell'Aquila et al. } \\
\quad(1997 b)\end{array}$ \\
\hline In vitro & 349 & $\begin{array}{l}\text { Heparin/Ca lonophore } \\
\text { A23187 }\end{array}$ & $11-30^{*}$ & & Alm et al. (2001) \\
\hline In vitro & 815 & Ca lonophore A23187 & $0-24 *$ & & Hinrichs et al. (2002) \\
\hline In vitro & 54 & Ca lonophore A23187 & 33 & 24 & Zhang et al. (1990) \\
\hline In vitro & 370 & Progesterone & 0 & & Tremoleda et al. (2003) \\
\hline In vitro & 385 & $\begin{array}{l}\text { Heparin/Ca lonophore } \\
\text { A23187/BSA }\end{array}$ & $0-40^{\mathrm{b}, *}$ & & Roasa et al. (2007) \\
\hline In vitro & 994 & Ca lonophore A23187 & $0-8^{*}$ & & Mugnier et al. (2009b) \\
\hline In vitro & 21 & Caffeine & 0 & & Mugnier et al. (2009a) \\
\hline \multirow[t]{2}{*}{ In vitro } & 74 & Procaine & $40-84^{\mathrm{c}, *}$ & & McPartlin et al. (2009) \\
\hline & & $10 \%$ follicular fluid & $19^{c}$ & & $\begin{array}{l}\text { Lange-Consiglio and } \\
\text { Cremonesi }(2011)\end{array}$ \\
\hline In vitro & 154 & Procaine & $38-62 *$ & & Ambruosi et al. (2013) \\
\hline
\end{tabular}

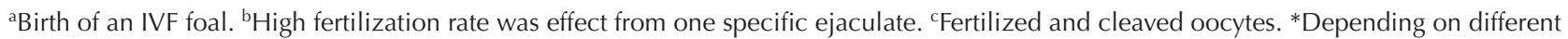
conditions tested.

procaine to induce hyperactivated motility (McPartlin et al. 2009). Similar results were subsequently reported by Ambruosi et al. (2013). However, seven years later, this technique has still not been validated by reports of blastocyst formation or the birth of IVF foals. Moreover, we recently demonstrated that procaine directly affects equine oocytes, inducing cytokinesis via a pH-dependent pathway (Leemans et al. 2015a). These findings have now been confirmed by Goudet et al. (2016). In this respect, both McPartlin et al. (2009) and Ambruosi et al. (2013) classified fertilization as the presence of at least two pronuclei or cleavage after an $18 \mathrm{~h}$ gamete co-incubation followed by an additional $24 \mathrm{~h}$ culture. However, this methodology would not allow definitive differentiation of true fertilization from parthenogenetic activation of an unfertilized oocyte. These results emphasize the need to assess the direct effect of chemical capacitation triggers on co-incubated oocytes and to evaluate fertilization more accurately, that is, by documenting sperm penetration (sperm mid-piece or tail visualization) and second polar body extrusion, rather than pronucleus formation alone.

Theoretically, the obstacles to equine IVF could reside at the level of either inadequate oocyte maturation or incomplete sperm capacitation. In this respect, it has been demonstrated that whereas IVF using in vivo matured oocytes is not successful (Palmer et al. 1991), in vitro matured oocytes transferred to the oviduct of an inseminated mare yield similar embryo development rates to spontaneous ovulations (Hinrichs et al. 2002). The latter observation confirms that in vitro matured oocytes are capable of being fertilized, which in turn suggests that equine capacitation or fertilization media lack one or more of the oviductal factors required for the spermatozoa to penetrate the zona pellucida and enter the oocyte. Moreover, there is little evidence that irreversible zona pellucida hardening resulting from premature cortical granule release triggered by suboptimal in vitro maturation conditions, or failure of oviductdependent changes in zona pellucida penetrability, play a role in the failure of equine IVF (Dell'Aquila et al. 1999). In short, the failure of equine IVF is most likely attributable to the inability of the spermatozoa to penetrate the zona pellucida as a result of inadequate activation (capacitation). In this respect, Tremoleda et al. (2003) found that while equine IVF conditions supported the binding of stallion spermatozoa to the zona pellucida they failed to induce either the acrosome reaction or characteristics typical of capacitation.

The high fertilization rates that occur after conventional insemination in vivo are generally accepted to be attributable to a capacitation-supporting oviductal environment (McPartlin et al. 2009). In this respect, the oviduct and its secretions provide an optimal environment for gamete maturation and interaction, including (1) transport of both male and female gametes to the site of fertilization, (2) final gamete maturation, (3) fertilization, (4) early embryonic development and (5) transport of the embryo to the uterus. It is hoped that incubating equine gametes with oviduct cells and their secretions in vitro will improve gamete preparation and activation to undergo fertilization and embryonic development (Li et al. 2001). More specifically, in-depth knowledge is required on how stallion spermatozoa 
are activated and acquire fertilizing capacity in the oviductal microenvironment, as a means of identifying the capacitation triggers missing in current capacitating/ fertilization media. To this end, this review focuses on equine sperm-oviduct interactions.

\section{Equine oviduct models for studying sperm-oviduct interactions in vitro: monolayers, explants and apical plasma membranes}

Establishing an in vitro equine oviduct model that faithfully recreates in vivo conditions would bring a working conventional equine IVF protocol within reach. While interactions between spermatozoa and the oviductal environment have been studied extensively in many mammals, little data is available for horse, in part because of the scarcity of equine reproductive tissues available to study this interaction. In addition, in vivo studies are challenging because invasive surgery or laparoscopy is required to access the oviduct. Several oviduct cell models have been developed, including oviduct epithelial cell monolayers (Thomas et al. 1995b, Dobrinski et al. 1999), explants (Nelis et al. 2014) and apical plasma membrane preparations (Smith \& Nothnick 1997) (Fig. 1).

Oviduct explants have several advantages over monolayers for studying sperm-oviduct interactions: (1) In cattle (Thibodeaux et al. 1992, Walter 1995) and horses (Thomas et al. 1995b, Dobrinski et al. 1999), proliferating oviduct epithelial cells grown in monolayers 'de-differentiate' exhibiting a reduction in cell height, and loss of cilia, secretory granule abundance and bulbous protrusions. In this respect, monolayers do not accurately reflect the in vivo situation (Thibodeaux et al. 1992, Walter 1995, Reischl et al. 1999), (2) Explants of bovine (Harvey et al. 1995, Walter 1995, De Pauw et al. 2002, Rottmayer et al. 2006) and equine (Nelis et al. 2014) oviduct epithelium maintain vigorously beating cilia, an important marker of cell viability. Nelis et al. (2014) showed that, even after 6 days in culture, equine oviduct epithelial explants still contained beating cilia and numerous microvilli, and confirmed this using transmission electron microscopy. Moreover, the epithelial cells lining the explants maintained a highly differentiated morphology, even at the ultrastructural level, characterized by numerous mitochondria and rough endoplasmic reticulum, similar to freshly harvested oviduct epithelium. (3) The secretion of insulin-like growth factor-2 (IGF2) from bovine oviduct explants was significantly higher than from monolayers, indicating better preservation of cell function (Winger et al. 1997). (4) Explants can be used as soon as 6-12 h after harvesting, whereas monolayers require several days of culture before they can be used (Rottmayer et al. 2006). (5) Bull sperm heads bind preferentially to the cilia or deeper regions of ciliated epithelial cells of explants rather than to secretory epithelial cells (Pollard et al. 1991, Petrunkina et al. 2001). In addition, both human (Baillie et al. 1997) and bovine (Sostaric et al. 2008) spermatozoa bind preferentially to explants compared to monolayers. (6) We found that stallion spermatozoa bound to oviduct explants undergo capacitation-related events like tail-associated protein tyrosine phosphorylation, confirming that the explants mimic some important in vivo functions (Leemans et al. 2014). In conclusion, explants are preferred for assessing the effect of sperm-oviduct epithelium binding on sperm physiology because they are the only current model in which oviduct epithelial secretory activity is maintained within physiological ranges (Nelis et al. 2014).

While the above properties favour the use of the more 'in vivo-like' oviduct explants, it is difficult to reliably quantify sperm-oviduct binding to explants because of their invaginated and irregular surface. Therefore, spermbinding studies are often performed using equine oviduct monolayers, which have a flat surface (Thomas et al. 1995b, Dobrinski et al. 1999). Alternatively, accurate quantification of sperm binding can be performed using oviduct apical plasma membranes coated onto nitrocellulose (Leemans et al. 2016). However, when using oviduct explants and apical plasma membranes in parallel, we were unable to identify significant differences in sperm binding, even though the number of spermatozoa bound per $\mathrm{mm}^{2}$ varied more using the explants with their irregular surface (Leemans et al. 2016).

\section{Sperm-oviduct binding: establishing a sperm reservoir}

After entering the oviduct during the peri-ovulatory period, spermatozoa bind to the oviduct epithelium to establish a sperm reservoir in the caudal isthmus and uterotubal junction (Boyle et al. 1987). In the mare, spermatozoa in the reservoir may need to survive relatively long periods, given the prolonged

$\begin{array}{ccc}\text { oviduct } & \text { oviduct } & \text { oviduct } \\ \text { MONOLAYER } & \text { EXPLANT } & \text { APM } \\ \text { model } & \text { model } & \text { model }\end{array}$
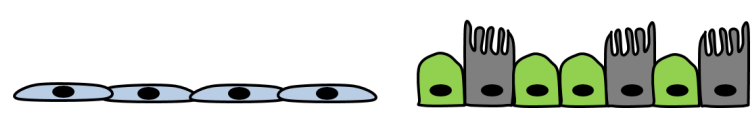

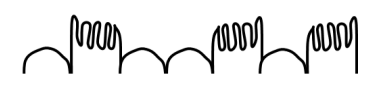

Figure 1 Different in vitro equine oviduct models to study various fertilization events. Each model has its advantages and disadvantages but depending on the aim of the study one model is more preferable than the other. 
duration of oestrus. It was hypothesized previously that the interaction between oviduct epithelial cells and spermatozoa serves various aims: (1) to provide an environment suitable for sperm storage and survival until ovulation; (2) to select a viable, morphologically normal and motile sperm population; (3) to prepare spermatozoa to capacitate and acquire the ability to fertilize a mature oocyte; and finally (4) to prevent polyspermic fertilization (Suarez 2002).

In cattle and horses, only viable spermatozoa with an intact acrosome and plasma membrane bind to the oviduct epithelium (Ellington et al. 1993c, Thomas et al. 1994a,b, Gualtieri \& Talevi 2000, Sostaric et al. 2008). In vitro, stallion spermatozoa bind to oviduct epithelial explants via the apical region of the sperm head (Thomas et al. 1994b). When using oviduct monolayers, sperm binding properties are not affected by cycle stage (Lefebvre \& Samper 1993) whereas, for equine oviduct explants, a higher sperm-oviduct binding capacity is observed when material is harvested during the immediate pre- and post-ovulatory periods, compared with later in the luteal phase (Thomas et al. 1994a). The latter study also showed that sperm tail-beating was higher when bound to oviduct explants harvested at the follicular stage than at other cycle stages. In addition, sperm-oviduct explant binding was better for isthmic than ampullary oviduct epithelial explants (Thomas et al. 1994a). It has also been demonstrated that direct membrane contact between stallion spermatozoa and oviduct cells in vitro results in (1) better maintenance of motility compared to spermatozoa incubated in the absence of oviduct cells (Ball et al. 1993, Ellington et al. 1993b, Ellington et al. 1999) and (2) a lower intracellular calcium concentration resulting in a delay in capacitation and prolonged viability of the bound spermatozoa (Dobrinski et al. 1996b, Dobrinski et al. 1997). An analogous scenario to the isthmic sperm reservoir in vivo might ensure the prolonged presence of a competent sperm subpopulation for activation and release at the time of fertilization.

\section{Key biochemical factors in equine sperm-oviduct binding}

In the mammalian oviduct, proteins present on the (outer) plasma membrane of non-capacitated spermatozoa recognize carbohydrate moieties on the surface of the plasma membrane of oviduct epithelial cells (Suarez 2001, 2002, Sostaric et al. 2005). In horses, it has been reported that both fetuin and asialofetuin block in vitro sperm-oviduct binding, with the latter doing so more potently. When the sialic acid is removed from fetuin, D-galactose is the principal carbohydrate exposed at the end of the oligosaccharide chains (Lefebvre et al. 1995). Indeed, a competitive inhibitory effect of D-galactose on sperm-oviduct binding in vitro has been demonstrated using an oviduct monolayer model (Lefebvre et al. 1995, Dobrinski et al. 1996a), while galactose-binding proteins were detected on the surface of stallion spermatozoa by Sabeur and Ball (2007). Galactosyl residues have also been shown to be highly expressed in the isthmic part of the equine oviduct (Ball et al. 1997), suggesting their involvement as ligands for sperm adhesion. These residues were less highly expressed in the ampulla where cycle-related differences were observed, characterized by maximum galactosyl expression during oestrus (Ball et al. 1997). Using an oviduct explant or apical plasma membrane model, we were unable to identify D-galactose as key molecule in equine sperm-oviduct interaction (Leemans et al. 2016). Similarly, immunohistochemistry failed to reveal expression of D-galactose on the equine oviduct epithelial plasma membrane, whereas other galactosyl carbohydrates were present, which supported the findings of a previous study (Desantis et al. 2004). Although various carbohydrates, including galactosyl moieties, were highly expressed on the epithelium of oviduct explants, we were unable to competitively inhibit sperm-oviduct epithelium binding using any of a variety of candidate mono- and polysaccharides, including D-galactose, and lectins. We did, however, find that, in contrast to some other mammalian species (Suarez 2001), equine sperm-oviduct explant binding was neither dependent on calcium nor on disulphide (S-S) covalent bonds (Leemans et al. 2016). In short, it appears that equine sperm-oviduct epithelium interaction in vivo is not based on a single lectin or S-S covalent bond.

One of the major seminal plasma proteins associated with the sperm plasma membrane is horse seminal plasma protein-7 (HSP-7). This protein is the equine homologue of the porcine spermadhesin, AWN (TopferPetersen et al. 2005). As a group, the HSP-7 interact with carbohydrates expressed on the oviduct epithelium and may, therefore, be involved in sperm reservoir formation. SP-1 and SP-2 (previously HSP-1 and HSP-2), which are members of the fibronectin-2 protein family, have also been identified in equine seminal plasma and are homologues of bovine seminal plasma proteins involved in establishing the bovine sperm oviduct reservoir (Ekhlasi-Hundrieser et al. 2005). Nevertheless, the role of HSPs in equine sperm-oviduct binding has yet to be fully elucidated.

Unfortunately, the nature of the oviduct receptor(s), which is/are responsible for equine sperm-oviduct binding is still unknown. Moreover, the specificity of equine sperm-oviduct binding, both in vitro and in vivo, is questionable. In vitro studies have suggested lectin interactions between spermatozoa and oviduct epithelial cells, which might represent either the totality or only a portion of the pre-ovulatory sperm-binding reaction. If the latter is true, a strong degree of nonspecific binding is present in vivo. This hypothesis was supported by studies that showed spermatozoa to have a 
MECHANISM 1

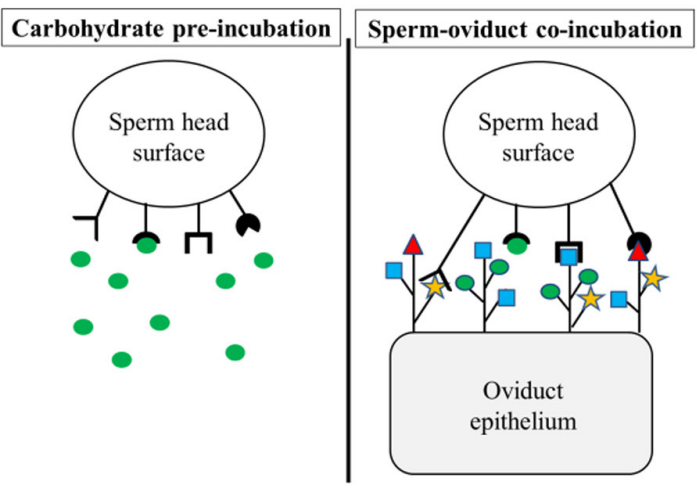

MECHANISM 3

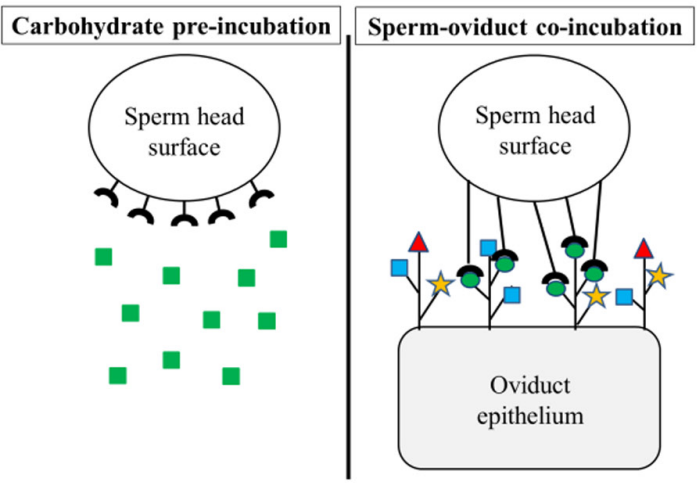

MECHANISM 2

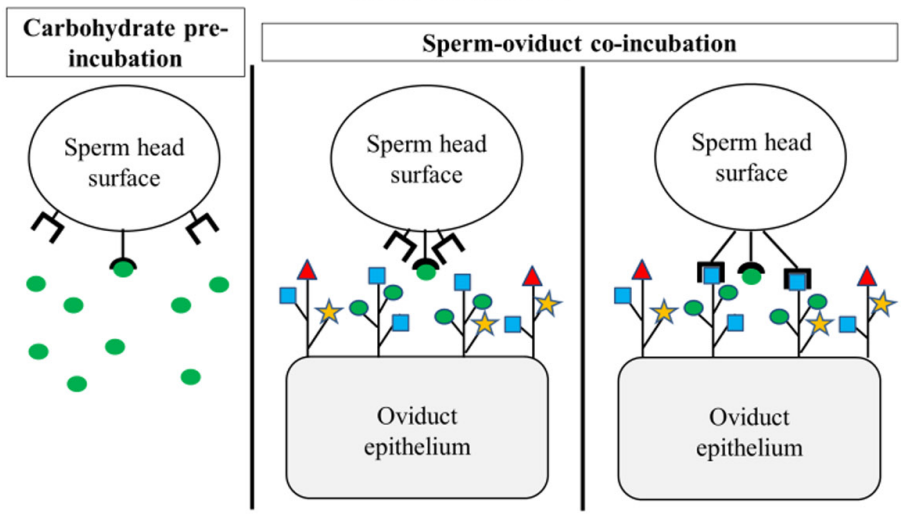

MECHANISM 4

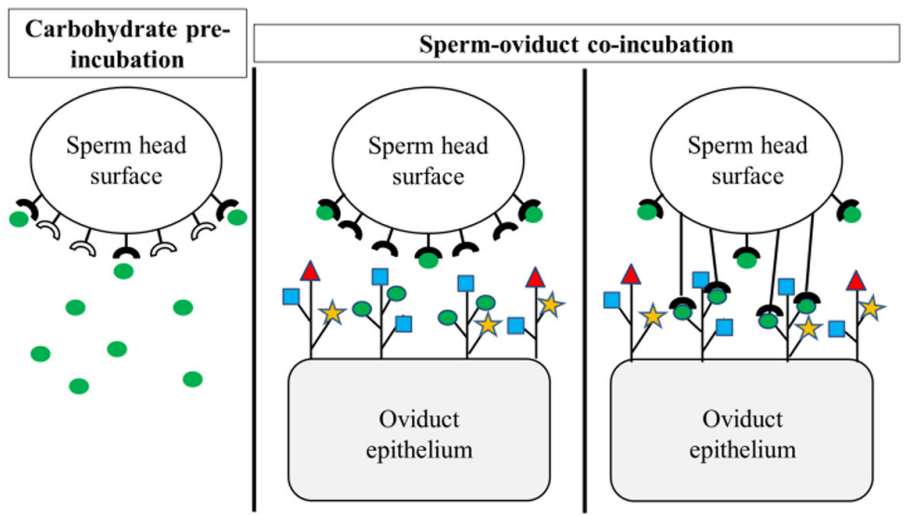

Figure 2 Four potential mechanisms that may be involved in equine sperm-oviduct binding that hypothesize why this interaction cannot be competed with (pre)incubation of one of the carbohydrates or lectins: (1) multiple protein-carbohydrate interactions are involved ('aspecific' binding nature), only the carbohydrate or lectin of choice partly and insufficiently blocks the interaction; (2) a primary-secondary carbohydrate ligand-receptor binding where a primary carbohydrate binding allows a secondary binding with another carbohydrate ligand expressed on the oviduct explant epithelium once the secondary binding is established; (3) not only the type of carbohydrate but also the carbohydrate conformation/isomer might be important; and (4) the lectin binding is dependent on multivalency and only cooperative lectin binding allows firm binding. (Pre)labelling of spermatozoa with the monomeric form of the carbohydrate involved in sperm-oviduct binding will not compete with the cooperative sperm-oviduct type of lectin binding. Only a small portion of the exposed lectins with high affinity on the sperm head is covered by the carbohydrate and a bigger portion has lower affinity and can only bind in cooperative manner to multivalent lectin binding sites at the oviduct epithelium. These sites remain operative after (pre)labelling with monomeric carbohydrates and thus sperm-oviduct binding cannot be competed.

similar binding capacity for tracheal epithelium, another type of ciliary epithelium (Hunter 2003, 2011).

Several hypotheses can be generated for the mechanism(s) of equine sperm-oviduct binding: (1) various carbohydrate-receptor interactions play a role; (2) a secondary binding response is triggered by interaction with a primary carbohydrate receptor; (3) not only the type of carbohydrate, but also the conformation/ isomer might be important; and (4) carbohydrates on both the oviduct and sperm cell surface might cooperate in sperm-oviduct binding. Carbohydrate-binding proteins typically have very shallow, solvent-exposed binding sites and make relatively few direct contacts with their target ligands. Thus, a key phenomenon in the specificity of such interactions is 'multivalency', that is multiple protein-carbohydrate interactions cooperating in a recognition event to achieve the necessary increased functional affinity (reviewed by del Carmen Fernandez-Alonso et al. 2012). As such, multiple receptors need to be arranged in a specific order to bind efficiently to multiple saccharide ligands (Kiessling \& Pohl 1996, Gabius et al. 2011). An overview of the different hypotheses is given in Fig. 2. In conclusion, the interaction between carbohydrates and their receptors is a very complex area, and in-depth studies are required to elucidate their role in equine sperm-oviduct binding.

\section{How are sperm cells released from oviduct epithelial cell binding?}

At the late pre-ovulatory stage, a select group of spermatozoa must be released from oviduct epithelium 
binding and migrate to the site of fertilization at the ampullary-isthmic junction. Theoretically, various mechanisms could contribute to sperm release: (1) a decrease in the availability of oviductal sperm-binding sites, (2) release in response to capacitation-related changes in the sperm plasma membrane, (3) secretion of molecules that compete for sperm-binding sites, (4) spermatozoa detaching as a result of acquiring hyperactivated motility, (5) spermatozoal contact with disulphide reductants, and (6) two or more of these mechanisms combine to trigger sperm cell release.

In horses, very little data is available on the mechanisms involved in releasing spermatozoa from oviduct epithelium binding. It has, however, been demonstrated that the intracellular calcium concentration in unbound stallion spermatozoa is many times higher than that in bound spermatozoa (Dobrinski et al. 1996b, Dobrinski et al. 1997), as it is in cattle spermatozoa (Gualtieri et al. 2005). In order to be released from oviduct epithelium binding, it is thought that sperm cells have to undergo capacitation. In this respect, stallion spermatozoa co-cultured with oviduct epithelial cell explants showed signs of capacitation, whereas spermatozoa cultured in similar conditions but without oviduct cells did not (Leemans et al. 2014). Similar findings were acquired using an oviduct monolayer model (Ellington et al. 1993a). The capacitated sperm population also showed an increased affinity for zona pellucida binding (Ellington et al. 1993a). Conversely, after previous exposure to calcium ionophore significantly fewer stallion spermatozoa are able to bind to oviduct monolayers. Moreover, oestradiol and heparin have been reported to trigger sperm release from oviduct epithelial cell monolayers (Thomas et al. 1995a) but using oviduct explants, we were unable to confirm this finding in case of heparin and disulphide reductants such as D-penicillamine (Leemans et al. 2016). Nevertheless, currently used equine capacitating media, which contain bicarbonate, calcium and albumin, do not trigger sperm release from oviduct explants (Leemans et al. 2016). Recently, we demonstrated that, of a range of potential physiological triggers, only heat-inactivated, charcoal-treated, $30 \mathrm{kDa}$ filtered or triple treated follicular fluid $(\mathrm{pH} \mathrm{7.9)}$ was able to induce hyperactivated motility and release of stallion spermatozoa bound to oviduct explants. However, while a significant proportion of bound spermatozoa showed hyperactivated motility combined with tail-associated protein tyrosine phosphorylation, only a small number of spermatozoa detached from the oviduct epithelium (Leemans et al. 2015b).

One obvious question is how many sperm cells need to be released from the oviductal reservoir to fertilize the oocyte at the moment of ovulation. A low sperm:egg ratio in vivo is essential to prevent polyspermy (Hunter 1996, 2012). The number of spermatozoa detaching from the epithelium and progressing to the site of fertilization in the peri-ovulatory period should, therefore, be strongly regulated by the oviduct. Just before ovulation, when an oocyte (or a small number of oocytes) will be released into the oviduct, only a small number of sperm cells should capacitate and detach from the oviduct epithelium, to ensure a low sperm:egg ratio at the isthmic-ampullary junction and reduce the risk of polyspermic fertilization (Smith \& Yanagimachi 1991, Hunter 1993, 2005, 2008, Suarez 2008). This hypothesis may explain the in vitro finding of very limited release of stallion spermatozoa from oviduct epithelium in hyperactivating, capacitating conditions. The stringent regulation of sperm release during the peri-ovulatory period in vivo is in sharp contrast to the progressively increasing post-ovulatory release of sperm cells, when it is too late to influence fertilization (Hunter 1996, 2005, 2012, Coy \& Aviles 2010, Coy et al. 2012).

\section{Is sperm binding to oviduct epithelium in the isthmic sperm reservoir indispensable for capacitation/fertilization?}

The caudal isthmus of the oviduct has been identified as a sperm reservoir in mares before ovulation (Bader 1982, Thomas et al. 1994a, Scott et al. 1995). However, it is less clear whether spermatozoa need to interact with oviduct epithelial cells in vivo to acquire fertilizing capacity. Indeed, when spermatozoa are directly introduced into the equine oviductal ampulla via the infundibulum, pregnancy rates are similar to those obtained after artificial insemination into the uterine body (McCue et al. 2000), suggesting that neither the uterine body nor the isthmus are obligatory stopping points on the route to capacitation/fertilization. On the other hand, stallion spermatozoa may need to interact with cells or fluids in the ampulla to capacitate/fertilize, whereas in many other species such as man, cattle and pig, sperm capacitation and fertilization can be achieved in vitro in the absence of any oviduct epithelia.

Exposing stallion spermatozoa in vitro to modified Whitten's medium containing both bicarbonate $(25 \mathrm{mM}$; $\mathrm{pH}=7.4$ ) and albumin significantly decreased the density of sperm binding to the oviduct epithelium, in association with a massively increased incidence of sperm head-to-head agglutination (Leemans et al. 2016). In the pig, sperm head-to-head agglutination is considered an early indicator of in vitro capacitation, signalling the removal of anti-agglutinin from the sperm surface (Lindahl \& Sjoblom 1981, Harayama et al. 1999, Harayama et al. 2000). Head-to-head agglutination in stallion spermatozoa might similarly indicate (1) the removal of sperm surface bound de-capacitation factors (seminal plasma proteins) and (2) early plasma membrane changes.

Intracellular alkalization and tail-associated protein tyrosine phosphorylation are other important hallmarks 
of capacitation. In this respect, in vitro oviduct-bound stallion spermatozoa showed higher rates of intracellular alkalization and protein tyrosine phosphorylation than unbound spermatozoa. Initially, we hypothesized that interaction between the sperm cells and the oviduct in vitro was required to switch on intracellular capacitation processes. However, the triggering of capacitation in oviduct explant-bound spermatozoa is more likely due to the release of 'pro-capacitating factors' from the secretory oviduct cells. Indeed, a similar protein tyrosine phosphorylation response was reported for stallion spermatozoa suspended in alkaline medium (Gonzalez-Fernandez et al. 2012, Aalberts et al. 2013). We recently demonstrated that the secretory cells in oviduct explants contain large alkaline vesicles (Leemans et al. 2014). Although discharge of these vesicles only marginally raised the $\mathrm{pH}$ of the incubation medium, they might nevertheless create an alkaline gradient around each oviduct explant. Moreover, in vivo any alkaline secretions would be diluted to a lesser extent by oviductal fluid and may therefore produce an alkaline local microenvironment sufficient to induce sperm protein tyrosine phosphorylation without sperm binding to the oviduct. In conclusion, a local increase in the bicarbonate concentration might be essential for stallion sperm capacitation (Liu et al. 2012).

Overall, the data suggest that exposure to oviduct secretions, secreted primarily by ampullary epithelium, may be more significant to the induction of capacitation in stallion spermatozoa than sperm-oviduct binding. We therefore suggest that in vivo sperm-oviduct binding and establishment of an oviductal sperm reservoir, is facultative rather than obligatory and depends on when, with respect to ovulation, the non-capacitated sperm cells enter the oviduct:

- If non-capacitated sperm cells arrive in the early preovulatory period, a significant sperm population will bind to the oviduct epithelium in the isthmus and form a sperm reservoir. These spermatozoa will be stored in the oviduct until capacitation triggers are generated just before ovulation.

- If non-capacitated sperm cells arrive in the periovulatory oviduct, the sperm cells immediately contact oviduct secretions containing the capacitation triggers and lose their oviduct-binding affinity. The fertilizing sperm cell(s) is/are not stored since fertilization should occur as soon as possible.

\section{What is the role of oviductal fluid in capacitation/ fertilization in the horse?}

\section{Composition of oviductal fluid}

Ovarian steroids, that is oestrogens and progesterone, regulate the composition of oviduct fluid that is produced by selective serum transudation, active biosynthesis and secretion from the oviduct secretory cells (Hunter \& Nichol 1988, Leese 1988). Additionally, follicular and peritoneal fluid enter the oviduct lumen. Oviduct cell secretory activity is region-dependent; the ampulla exhibits the highest secretory activity, the infundibulum intermediate and the isthmus has the least secretory activity (sheep: (Buhi et al. 1991); pig: (Buhi et al. 1992); horse: (McDowell et al. 1993)). The volume of oviduct fluid is also cycle-dependent with the largest volume measured during the follicular phase under oestrogen influence (cattle: (Malayer et al. 1988, Buhi et al. 1989); pig: (Buhi et al. 1989); mare: (Campbell et al. 1979)).

To date, only very few oviduct secreted factors that might modulate gamete preparation for fertilization have been studied. Oestrogen-dependent oviduct secretory glycoprotein (OSG) or oviductin is a unique oviduct protein conserved across many mammalian species. OSG enhances sperm-oocyte binding and penetration through the zona pellucida, and also plays a role in early embryonic development (cattle: (Boice et al. 1990); sheep: (Murray 1993); pig: (Kouba et al. 2000)). However, when searching the equine genome Mugnier et al. (2009a) were only able to find an OSG-like gene that included stop codons, which they concluded might be a pseudogene. Nevertheless, it is possible that the failure to identify a functional OSG gene was due to species-specific differences in the sequence and incomplete annotation of the equine genome, rather than true absence of this gene in the horse.

Osteopontin, atrial natriuretic peptide A (ANP A) and deleted in malignant brain tumor 1 (DMBT1), have been specifically identified as oviduct secretory proteins in the horse. When stallion spermatozoa were capacitated with calcium ionophore, co-incubation of mature equine oocytes with either equine or porcine oviduct epithelial explants or monolayers increased equine IVF rates ( 9 vs $0 \%$ in controls). Although there was no significant effect of osteopontin or ANP A on fertilization, osteopontin slightly improved the IVF rates (Mugnier et al. 2009a). Moreover, Ambruosi et al. (2013) reported increased monospermic fertilization rates when mature equine oocytes were pre-incubated with DMBT1 and subsequently fertilized by procainecapacitated spermatozoa.

There are further unidentified oviduct secreted proteins with affinity for the sperm plasma membrane or that affect final maturation of the equine oocyte (Battut et al. 1995). However, little is known about their function in the equine oviduct (Goudet 2011).

Besides proteins, many other factors including electrolytes (e.g. calcium, bicarbonate), lipids (including steroids) and carbohydrates contribute to the composition of oviductal fluid to create optimal fertilization conditions. The exact effect on capacitation/fertilization is poorly understood. The ion concentrations in the oviductal fluid of mares tend to be similar to those in serum (Aguilar \& Reyley 2005), with the exception of magnesium, which 
is present in concentrations 2-5 times higher than in plasma (Campbell et al. 1979) and much higher than in other species (Aguilar \& Reyley 2005).

\section{Acid-base balance of oviductal fluid}

The acid-base balance in both the male and female reproductive tracts is finely modulated (Pastor-Soler et al. 2005, Lishko et al. 2012). The male reproductive tract and more specifically the epididymis contains acidic luminal fluid ( $\mathrm{pH} \approx 6.5 ; 3-4 \mathrm{mM}$ bicarbonate) (Levine \& Marsh 1971, Acott \& Carr 1984, Carr et al. 1985, Rodriguez-Martinez et al. 1990), which renders mature spermatozoa quiescent. As a result of bicarbonate secretion in the cauda epididymis, the $\mathrm{pH}$ increases slightly and the spermatozoa acquire progressive motility. During ejaculation, spermatozoa are mixed with seminal plasma resulting in a further increase of the $\mathrm{pH}$ to 7.2 (25-30 mM bicarbonate) (Rodriguez-Martinez et al. 1990). However, seminal plasma also contains de-capacitation factors that inhibit capacitation. In contrast, female reproductive tract luminal fluids, that is the uterus and in particular the oviduct, tend to be alkaline $(\mathrm{pH} \approx 7.6-7.8)$ (Vishwakarma 1962, Murdoch \& White 1968, Maas et al. 1977). In the uterus, spermatozoa are still mixed with seminal plasma whereas upon entering the oviduct the sperm cells are separated from the seminal plasma de-capacitation factors (reviewed by Liu et al. (2012)).

It has also been suggested that in the peri-ovulatory period, the luminal fluids of the mare's genital tract also exhibit an increased, slightly alkaline $\mathrm{pH}$. The following findings support this theory: (1) When untreated stallion semen was introduced into the uterus of oestrous mares and retrieved $30 \mathrm{~min}$ later, the $\mathrm{pH}$ increased from 7.47 to 7.85 (Gonzalez-Fernandez et al. 2012). (2) We showed that the number of alkaline secretory vesicles in the epithelium of oviduct explants decreased significantly during sperm binding, and suggest that this generates an alkaline local microenvironment that stimulates capacitation in vitro (Leemans et al. 2014). (3) In response to these alkaline conditions ( $\mathrm{pH} 7.9$ ), stallion spermatozoa show (a) a decreased affinity for oviduct epithelium binding and increased propensity for head-to-head agglutination (Leemans et al. 2016), (b) a gradual increase in intracellular $\mathrm{pH}$ associated with increased protein tyrosine phosphorylation of proteins in the sperm tail (Gonzalez-Fernandez et al. 2012, Aalberts et al. 2013, Leemans et al. 2014), and (c) hyperactivated motility which facilitates a limited release of spermatozoa from oviduct binding (Leemans et al. 2015b). To date, however, the $\mathrm{pH}$ of equine oviduct fluid has not been measured during the peri-ovulatory period secretory phase of the oviduct epithelium. Nevertheless, we have strong evidence that an alkaline $\mathrm{pH}$ in the mare's oviduct during the late pre-ovulatory period is important for preparing stallion spermatozoa for fertilization.

\section{Does follicular fluid have an additional effect on capacitation/fertilization?}

At ovulation, the majority of the follicular fluid passes through the fimbriae into the peritoneal cavity, but a small proportion enters the infundibulum of the oviduct (Ginther et al. 2008). This small volume of follicular fluid might nevertheless influence the oviductal microenvironment because it contains factors capable of activating or capacitating spermatozoa present in the oviduct, as already demonstrated in man (Fetterolf et al. 1994a,b, Yao et al. 2000), cattle (Sostaric et al. 2005), hamster (Yanagimachi 1969) and rabbit (Harper $1973 a, b)$. In this respect, progesterone has been designated as a key factor in the capacitation of human spermatozoa (Harper et al. 2004, Publicover et al. 2007, Lishko et al. 2011, Strunker et al. 2011), while in cattle

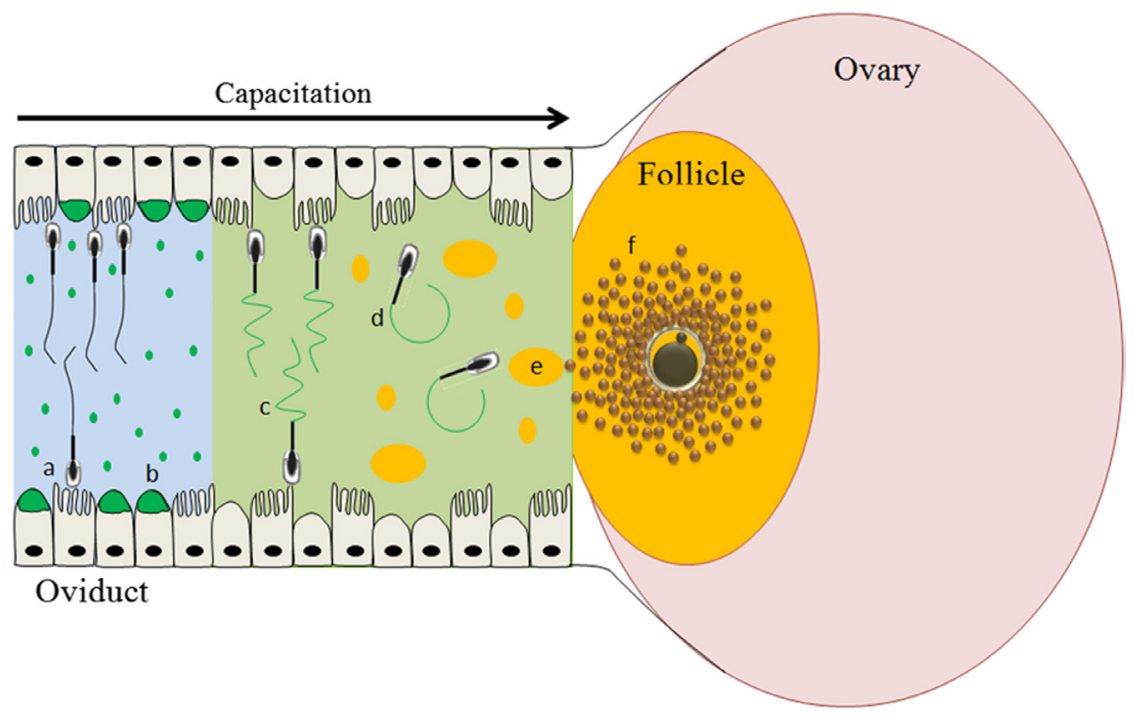

Figure 3 Three hypotheses explaining which in vivo biological oviduct factors are involved in stallion sperm capacitation - sperm release - fertilization. The missing capacitation/ fertilization factors might be originating from (1) a mix of alkaline oviduct secretions and follicular fluid components, (2) the oocyte anchored with cumulus cell secretions and (3) oviduct epithelium secretions. (A: Spermoviduct binding, B: secretion of the alkaline vesicles of the secretory epithelial cells, C: induction of hypermotility and tailassociated protein tyrosine phosphorylation, D: release of sperm from oviduct epithelium, E: a small amount of follicular fluid enters the oviduct after ovulation and F: the oocyte anchored with cumulus cells will be shedded in the oviduct as well). 
glycosaminoglycans have been identified as the key activators of capacitation (Sostaric et al. 2005). In horse, little is known about capacitation factors in follicular fluid, although progesterone has been proposed as a likely candidate (Cheng et al. 1998a,b, Rathi et al. 2003).

We initially hypothesized that a mix of oviductal secretions and follicular fluid components must induce sperm capacitation in the equine peri-ovulatory oviduct (Hypothesis 1) because we had shown that the combined effect of an elevated environmental $\mathrm{pH}$, external calcium and unidentified follicular fluid factor(s) (heat-resistant, hydrophilic factor $<30 \mathrm{kDa}$ ) induced hyperactivation, tail-associated protein tyrosine phosphorylation and sperm release from the oviduct epithelium (Leemans et al. 2015b). However, the physiological relevance of hypothesis 1 is questionable because pre-ovulatory follicular fluid is not alkaline $(\mathrm{pH} \pm 7.2)$ (Leemans et al. 2015b). Instead, capacitation in the narrow and tortuous oviductal lumen might be induced by oviductal fluid alone, while the unidentified follicular fluid factor(s) might also be secreted by cumulus cells anchored to the oocyte (Hypothesis 2) and the oviduct epithelium (Hypothesis 3) (Fig. 3). In the latter scenario, the fact that we observed protein tyrosine phosphorylation only in sperm bound to oviduct explants (Leemans et al. 2014) might reflect a dilution gradient of pro-capacitating factors in which the secretory epithelial cells generated the appropriate alkaline local microenvironment whereas the concentration of the unidentified follicular fluid factor(s) may have been too low to induce the other capacitation events such as hyperactivated motility and plasma membrane fluidity. It is also noted that co-incubation of stallion spermatozoa with cumulus-oocyte complexes did not trigger any capacitation-related parameters (unpublished data).

\section{Further considerations}

Since the in vitro oviduct models used have their specific limitations, and in vivo collection of oviduct fluid is very challenging, a 3D oviduct model may provide a valuable in vitro alternative. Recently, nanotechnologies such as microfluidic automation, that is the automated routing, dispensing, mixing and separation of fluids through microchannels, via 3D prints and inserts have been introduced in attempts to more closely mimic an in vitro oviduct model that better recapitulates physiological function. For example in pig, IVF of porcine oocytes in microchannels resulted in a higher incidence of monospermic fertilization than in oocytes fertilized in the traditional microdrop system, despite comparable penetration and male pronucleus formation rates (Clark et al. 2005). In horse, further research could usefully focus on cultivating oviductal cells in microfluidic channels. The switch from a static to a more dynamic model should generate a more robust oviduct epithelium cell model in terms of morphological, ultrastructural and physiological features. Currently, a 3D oviduct culture system is being developed in horse and in cow (Dr Gadella and Dr Stout, personal communication), in which oviduct epithelial cells maintain or re-establish their in vivo-like differentiation status and function. Preliminary observations have already shown that spermatozoa can bind to the zona pellucida and subsequently acrosome react, which is followed by partial penetration of the zona pellucida. This has been achieved in a medium that was conditioned by epithelial cells, but in the absence of any exogenous capacitation factors. A basolateral microperfusion system that allows creation of the peri-ovulatory ovarian steroid endocrine shift to induce changes in the secretion of epithelial cells in an oviduct culture insert is currently being designed. The applicability of such systems to aid equine IVF is a viable topic for future study, but it will almost certainly deepen our understanding of gamete-oviduct interaction, including sperm capacitation, fertilization and early embryo development. Ultimately, after identifying capacitation triggers, a redefined capacitating medium incorporating the primary capacitating/fertilization triggers might then be established and finally enable successful IVF in the horse.

\section{Conclusion}

For more than 25 years, co-incubation of mature oocytes with capacitated spermatozoa has been the standard method for producing in vitro embryos in several species including man, cattle, pigs and many laboratory animals. However, conventional IVF is still not reliably successful using equine gametes. Inadequate capacitation of stallion spermatozoa under in vitro conditions is almost certainly the major obstacle to the failure of equine IVF. We hypothesize that one or more oviduct-derived factor(s) is/are indispensable to adequate triggering of capacitation to enable stallion sperm cells to penetrate an oocyte. The key capacitating factor composition of oviduct fluid is usually mimicked in vitro to establish an efficient capacitation/fertilization medium. The effect of increased local $\mathrm{pH}$ on capacitation strongly suggests that equine sperm capacitation/fertilization media require a higher $\mathrm{pH}$ than for other mammalian species. However, even these capacitating conditions do not induce the acrosome reaction and allow successful equine IVF. In the future, the role of oviduct fluid components on equine IVF should be further elucidated by new technologies such as 3D oviduct printing and microfluidic automation.

\section{Declaration of interest}

The authors declare that there is no conflict of interest that could be perceived as prejudicing the impartially of this review. 


\section{Funding}

This work was supported by the Agency for Innovation in Science and Technology (IWT-Flanders; grant number 101521).

\section{References}

Aalberts M, Sostaric E, Wubbolts R, Wauben MW, Nolte-'t Hoen EN, Gadella BM, Stout TA \& Stoorvogel W 2013 Spermatozoa recruit prostasomes in response to capacitation induction. Biochimica et Biophysica Acta 1834 2326-2335. (doi:10.1016/j. bbapap.2012.08.008)

Acott TS \& Carr DW 1984 Inhibition of bovine spermatozoa by caudal epididymal fluid: II. Interaction of $\mathrm{pH}$ and a quiescence factor. Biology of Reproduction 30 926-935. (doi:10.1095/biolreprod30.4.926)

Aguilar J \& Reyley M 2005 The uterine tubal fluid: secretion, composition and biological effects. Animal Reproduction 2 91-105.

Alm H, Torner H, Blottner S, Nurnberg G \& Kanitz W 2001 Effect of sperm cryopreservation and treatment with calcium ionophore or heparin on in vitro fertilization of horse oocytes. Theriogenology 56 817-829. (doi:10.1016/S0093-691X(01)00610-0)

Ambruosi B, Accogli G, Douet C, Canepa S, Pascal G, Monget P, Moros Nicolas C, Holmskov U, Mollenhauer J, Robbe-Masselot C et al. 2013 Deleted in malignant brain tumor 1 is secreted in the oviduct and involved in the mechanism of fertilization in equine and porcine species. Reproduction 146 119-133. (doi:10.1530/REP-13-0007)

Bader H 1982 An investigation of sperm migration into the oviducts of the mare. Journal of Reproduction and Fertility Supplement 32 59-64.

Baillie HS, Pacey AA, Warren MA, Scudamore IW \& Barratt CL 1997 Greater numbers of human spermatozoa associate with endosalpingeal cells derived from the isthmus compared with those from the ampulla. Human Reproduction 12 1985-1992. (doi:10.1093/humrep/12.9.1985)

Ball BA, Brinsko SP, Thomas PGA, Miller PG \& Ellington JE 1993 Development to blastocysts of one-cell to 2-cell equine embryos after coculture with uterine tubal epithelial-cells. American Journal of Veterinary Research 54 1139-1144.

Ball BA, Dobrinski I, Fagnan MS \& Thomas PG 1997 Distribution of glycoconjugates in the uterine tube (oviduct) of horses. American Journal of Veterinary Research $\mathbf{5 8} 816-822$.

Battut I, Palmer E \& Driancourt M 1995 Proteins synthesized and released by equine oviducts: characterization, variations, and interactions with spermatozoa. In Equine Reproduction VI, pp 131-140. Eds DC Sharp \& FW Bazer. Madison, WI: SSR.

Betteridge KJ 2006 Farm animal embryo technologies: achievements and perspectives. Theriogenology 65 905-913. (doi:10.1016/j. theriogenology.2005.09.005)

Bézard J, Magistrini M, Battut I, Duchamp G \& Palmer E 1992 In vitro fertilization in the mare. Recueil de Medecine Veterinaire 168 993-1003.

Boice ML, Geisert RD, Blair RM \& Verhage HG 1990 Identification and characterization of bovine oviductal glycoproteins synthesized at estrus. Biology of Reproduction 43 457-465. (doi:10.1095/biolreprod43.3.457)

Boyle MS, Cran DG, Allen WR \& Hunter RH 1987 Distribution of spermatozoa in the mare's oviduct. Journal of Reproduction and Fertility Supplement 35 79-86.

Buhi WC, Ashworth CJ, Bazer FW \& Alvarez IM 1992 In vitro synthesis of oviductal secretory proteins by estrogen-treated ovariectomized gilts. Journal of Experimental Zoology 262 426-435. (doi:10.1002/ jez.1402620409)

Buhi WC, Bazer FW, Alvarez IM \& Mirando MA 1991 In vitro synthesis of oviductal proteins associated with estrus and 17 beta-estradiol-treated ovariectomized ewes. Endocrinology 128 3086-3095. (doi:10.1210/ endo-128-6-3086)

Buhi WC, Vallet JL \& Bazer FW 1989 De novo synthesis and release of polypeptides from cyclic and early pregnant porcine oviductal tissue in explant culture. Journal of Experimental Zoology 252 79-88. (doi:10.1002/jez.1402520111)

Campbell DL, Douglas LW \& Ramge JC 1979 Cannulation of the equine oviduct and chemical analysis of oviduct fluid. Theriogenology 12 47-59. (doi:10.1016/0093-691X(79)90009-8)
Carr DW, Usselman MC \& Acott TS 1985 Effects of pH, lactate, and viscoelastic drag on sperm motility: a species comparison. Biology of Reproduction 33 588-595. (doi:10.1095/biolreprod33.3.588)

Cheng FP, Fazeli AR, Voorhout WF, Tremoleda JL, Bevers MM \& Colenbrander B 1998a Progesterone in mare follicular fluid induces the acrosome reaction in stallion spermatozoa and enhances in vitro binding to the zona pellucida. International Journal of Andrology 21 57-66. (doi:10.1046/j.1365-2605.1998.00096.x)

Cheng FP, Gadella BM, Voorhout WF, Fazeli A, Bevers MM \& Colenbrander B 1998b Progesterone-induced acrosome reaction in stallion spermatozoa is mediated by a plasma membrane progesterone receptor. Biology of Reproduction 59 733-742. (doi:10.1095/biolreprod59.4.733)

Choi YH, Okada Y, Hochi S, Braun J, Sato K \& Oguri N 1994 In-vitro fertilization rate of horse oocytes with partially removed zonae. Theriogenology 42 795-802. (doi:10.1016/0093-691X(94)90448-R)

Clark SG, Haubert K, Beebe DJ, Ferguson CE \& Wheeler MB 2005 Reduction of polyspermic penetration using biomimetic microfluidic technology during in vitro fertilization. Lab on a Chip 5 1229-1232. (doi:10.1039/b504397m)

Coy P \& Aviles M 2010 What controls polyspermy in mammals, the oviduct or the oocyte? Biological Reviews of the Cambridge Philosophical Society 85 593-605. (doi:10.1111/j.1469-185X.2009.00117.x)

Coy P, Garcia-Vazquez FA, Visconti PE \& Aviles M 2012 Roles of the oviduct in mammalian fertilization. Reproduction 144 649-660. (doi:10.1530/REP-12-0279)

De Pauw IM, Van Soom A, Laevens H, Verberckmoes S \& de Kruif A 2002 Sperm binding to epithelial oviduct explants in bulls with different nonreturn rates investigated with a new in vitro model. Biology of Reproduction 67 1073-1079. (doi:10.1095/biolreprod67.4.1073)

del Carmen Fernandez-Alonso M, Diaz D, Berbis MA, Marcelo F, Canada J \& Jimenez-Barbero J 2012 Protein-carbohydrate interactions studied by NMR: from molecular recognition to drug design. Current Protein and Peptide Science 13 816-830. (doi:10.2174/138920312804871175)

Dell'Aquila ME, Cho YS, Minoia P, Traina V, Fusco S, Lacalandra GM \& Maritato F 1997a Intracytoplasmic sperm injection (ICSI) versus conventional IVF on abottoir-derived and in vitro-matured equine oocytes. Theriogenology 47 1139-1156. (doi:10.1016/S0093691X(97)00095-2)

Dell'Aquila ME, Cho YS, Minoia P, Traina V, Lacalandra GM \& Maritato F $1997 \mathrm{~b}$ Effects of follicular fluid supplementation of in-vitro maturation medium on the fertilization and development of equine oocytes after in-vitro fertilization or intracytoplasmic sperm injection. Human Reproduction 12 2766-2772. (doi:10.1093/humrep/12.12.2766)

Dell'Aquila ME, De Felici M, Massari S, Maritato F \& Minoia P 1999 Effects of fetuin on zona pellucida hardening and fertilizability of equine oocytes matured in vitro. Biology of Reproduction 61 533-540. (doi:10. 1095/?biolreprod61.2.533)

Dell'aquila ME, Fusco S, Lacalandra GM \& Maritato F 1996 In vitro maturation and fertilization of equine oocytes recovered during the breeding season. Theriogenology 45 547-560. (doi:10.1016/0093691X(95)00402-T)

Desantis S, Acone F, Corriero A, Deflorio M, Zubani D, Ventriglia G, Palmieri G \& De Metrio G 2004 Distribution of sialoglycoconjugates in the oviductal isthmus of the horse during anoestrus, oestrus and pregnancy: a lectin histochemistry study. European Journal of Histochemistry 48 403-412. (doi:10.4081/914)

Dobrinski I, Ignotz GG, Thomas PG \& Ball BA 1996a Role of carbohydrates in the attachment of equine spermatozoa to uterine tubal (oviductal) epithelial cells in vitro. American Journal of Veterinary Research $\mathbf{5 7}$ 1635-1639.

Dobrinski I, Suarez SS \& Ball BA 1996b Intracellular calcium concentration in equine spermatozoa attached to oviductal epithelial cells in vitro. Biology of Reproduction 54 783-788. (doi:10.1095/biolreprod54.4.783)

Dobrinski I, Jacob JR, Tennant BC \& Ball BA 1999 Generation of an equine oviductal epithelial cell line for the study of sperm-oviduct interactions. Theriogenology 52 875-885. (doi:10.1016/S0093-691X(99)00179-X)

Dobrinski I, Smith TT, Suarez SS \& Ball BA 1997 Membrane contact with oviductal epithelium modulates the intracellular calcium concentration of equine spermatozoa in vitro. Biology of Reproduction 56 861-869. (doi:10.1095/biolreprod56.4.861)

Ekhlasi-Hundrieser M, Schafer B, Kirchhoff C, Hess O, Bellair S, Muller P \& Topfer-Petersen E 2005 Structural and molecular characterization of equine sperm-binding fibronectin-II module proteins. 
Molecular Reproduction and Development 70 45-57. (doi:10.1002/ mrd.20187)

Ellington JE, Ball BA \& Yang X 1993a Binding of stallion spermatozoa to the equine zona pellucida after coculture with oviductal epithelial cells. Journal of Reproduction and Fertility 98 203-208. (doi:10.1530/ jrf.0.0980203)

Ellington JE, Ignotz GG, Miller PG, Curie WB \& Meyers-Wallen VN 1993b Oviduct epithelial cell co-culture modifies stallion and bull sperm cell proteins. Biology of Reproduction Supplement 1107.

Ellington JE, Varner DD, Burghardt RC, Meyers-Wallen VN, Barhoumi R, Brinsko SP \& Ball BA 1993c Cell-to-cell communication of equine uterine tube (oviduct) cells as determined by anchored cell analysis in culture. Animal Reproduction Science 30 313-324. (doi:10.1016/03784320(93)90081-2)

Ellington JE, Samper J, Jones A, Oliver SA, Burnett K \& Wright RW 1999 Effects of bovine serum albumin on function of cryopreserved stallion spermatozoa during medium culture and uterine tube epithelial cell coculture. American Journal of Veterinary Research 60 363-367.

Fetterolf PM, Jurisicova A, Tyson JE \& Casper RF 1994a Conditioned medium from human cumulus oophorus cells stimulates human sperm velocity. Biology of Reproduction 51 184-192. (doi:10.1095/ biolreprod51.2.184)

Fetterolf PM, Sutherland CS, Josephy PD, Casper RF \& Tyson JE 1994b Preliminary characterization of a factor in human follicular fluid that stimulates human spermatozoa motion. Human Reproduction 9 1505-1511.

Gabius HJ, Andre S, Jimenez-Barbero J, Romero A \& Solis D 2011 From lectin structure to functional glycomics: principles of the sugar code. Trends in Biochemical Sciences 36 298-313. (doi:10.1016/j. tibs.2011.01.005)

Galli C, Duchi R, Crotti G, Turini P, Ponderato N, Colleoni S, Lagutina I \& Lazzari G 2003 Bovine embryo technologies. Theriogenology 59 599-616. (doi:10.1016/S0093-691X(02)01243-8)

Ginther OJ, Gastal EL, Gastal MO \& Beg MA 2008 Dynamics of the equine preovulatory follicle and periovulatory hormones: what's new? Journal of Equine Veterinary Science 28 454-460. (doi:10.1016/j. jevs.2008.07.008)

Gonzalez-Fernandez L, Macias-Garcia B, Velez IC, Varner DD \& Hinrichs K 2012 Calcium-calmodulin and $\mathrm{pH}$ regulate protein tyrosine phosphorylation in stallion sperm. Reproduction 144 411-422. (doi:10.1530/REP-12-0067)

Goudet G 2011 Fertilisation in the horse and paracrine signalling in the oviduct. Reproduction, Fertility and Development 23 941-951. (doi:10.1071/RD10285)

Goudet G, Douet C, Kaabouba-Escurier A, Couty I, Moros-Nicolas C, Barriere P, Blard T, Reigner F, Deleuze S \& Magistrini M 2016 Establishment of conditions for ovum pick up and IVM of jennies oocytes toward the setting up of efficient IVF and in vitro embryos culture procedures in donkey (Equus asinus). Theriogenology 86 528-535. (doi:10.1016/j.theriogenology.2016.02.004)

Graham JK 1996 Methods for induction of capacitation and the acrosome reaction of stallion spermatozoa. Veterinary Clinics of North America: Equine Practice 12 111-117.

Gualtieri R, Boni R, Tosti E, Zagami M \& Talevi R 2005 Intracellular calcium and protein tyrosine phosphorylation during the release of bovine sperm adhering to the fallopian tube epithelium in vitro. Reproduction $\mathbf{1 2 9}$ 51-60. (doi:10.1530/rep.1.00374)

Gualtieri R \& Talevi R 2000 In vitro-cultured bovine oviductal cells bind acrosome-intact sperm and retain this ability upon sperm release. Biology of Reproduction 62 1754-1762. (doi:10.1095/biolreprod62.6.1754)

Harayama H, Liao PC, Gage DA, Miyake M, Kato S \& Hammerstedt RH 2000 Biochemical characterization of sialoprotein 'anti-agglutinin' purified from boar epididymal and seminal plasma. Molecular Reproduction and Development 55 96-103. (doi:10.1002/(SICI)10982795(200001)55:1\&lt;96::AID-MRD13\&gt;3.0.CO;2-J)

Harayama H, Magargee SF, Kunze E, Shidara O, Iwamoto E, Arikawa S, Miyake M, Kato S \& Hammerstedt RH 1999 Changes in epididymal protein anti-agglutinin on ejaculated boar spermatozoa during capacitation in vitro. Reproduction, Fertility and Development 11 193-199. (doi:10.1071/RD99056)

Harper CV, Barratt CL \& Publicover SJ 2004 Stimulation of human spermatozoa with progesterone gradients to simulate approach to the oocyte. Induction of $[\mathrm{Ca}(2+)](\mathrm{i})$ oscillations and cyclical transitions in flagellar beating. Journal of Biological Chemistry 279 46315-46325. (doi:10.1074/jbc.M401194200)

Harper MJ 1973a Relationship between sperm transport and penetration of eggs in the rabbit oviduct. Biology of Reproduction 8 441-450.

Harper MJ 1973b Stimulation of sperm movement from the isthmus to the site of fertilization in the rabbit oviduct. Biology of Reproduction $\mathbf{8}$ 369-377.

Harvey MB, Arcellanapanlilio MY, Zhang X, Schultz GA \& Watson AJ 1995 Expression of genes encoding antioxidant enzymes in preimplantation mouse and cow embryos and primary bovine oviduct cultures employed for embryo coculture. Biology of Reproduction 53 532-540. (doi:10.1095/biolreprod53.3.532)

Hinrichs K, Love CC, Brinsko SP, Choi YH \& Varner DD 2002 In vitro fertilization of in vitro-matured equine oocytes: effect of maturation medium, duration of maturation, and sperm calcium ionophore treatment, and comparison with rates of fertilization in vivo after oviductal transfer. Biology of Reproduction 67 256-262. (doi:10.1095/ biolreprod67.1.256)

Hunter RH 1993 Sperm:egg ratios and putative molecular signals to modulate gamete interactions in polytocous mammals. Molecular Reproduction and Development 35 324-327. (doi:10.1002/ mrd.1080350315)

Hunter RH 1996 Ovarian control of very low sperm/egg ratios at the commencement of mammalian fertilisation to avoid polyspermy. Molecular Reproduction and Development 44 417-422. (doi:10.1002/ (SICI)1098-2795(199607)44:3\&lt;417::AID-MRD15\&gt;3.0.CO;2-X)

Hunter RH 2003 Reflections upon sperm-endosalpingeal and sperm-zona pellucida interactions in vivo and in vitro. Reproduction in Domestic Animals 38 147-154. (doi:10.1046/j.1439-0531.2003.00402.x)

Hunter RH 2005 Fallopian tube physiology: preliminaries to monospermic fertilization and cellular events post-fertilization. Ernst Schering Research Foundation Workshop 245-261. (doi:10.1007/3-540-27147-3_11)

Hunter RH 2008 Sperm release from oviduct epithelial binding is controlled hormonally by peri-ovulatory graafian follicles. Molecular Reproduction and Development 75 167-174. (doi:10.1002/mrd.20776)

Hunter RH 2011 Sperm head binding to epithelium of the oviduct isthmus is not an essential preliminary to mammalian fertilization - review. Zygote 19 265-269. (doi:10.1017/S0967199410000341)

Hunter RH 2012 Components of oviduct physiology in eutherian mammals. Biological Reviews of the Cambridge Philosophical Society 87 244-255. (doi:10.1111/j.1469-185X.2011.00196.x)

Hunter RH \& Nichol R 1988 Capacitation potential of the fallopian tube: a study involving surgical insemination and the subsequent incidence of polyspermy. Gamete Research 21 255-266. (doi:10.1002/ mrd.1120210307)

Kiessling LL \& Pohl NL 1996 Strength in numbers: non-natural polyvalent carbohydrate derivatives. Chemistry and Biology 3 71-77. (doi:10.1016/ S1074-5521(96)90280-X)

Kouba AJ, Abeydeera LR, Alvarez IM, Day BN \& Buhi WC 2000 Effects of the porcine oviduct-specific glycoprotein on fertilization, polyspermy, and embryonic development in vitro. Biology of Reproduction 63 242-250. (doi:10.1095/biolreprod63.1.242)

Lange-Consiglio A \& Cremonesi F 2011 Hyperactivation of stallion sperm in follicular fluid for in vitro fertilization of equine oocytes. Reproduction, Fertility and Development 24 193-194.

Leemans B, Gadella BM, Sostaric E, Nelis H, Stout TA, Hoogewijs M \& Van Soom A 2014 Oviduct binding and elevated environmental pH induce protein tyrosine phosphorylation in stallion spermatozoa. Biology of Reproduction 91 13. (doi:10.1095/biolreprod.113.116418)

Leemans B, Gadella BM, Stout TA, Heras S, Smits K, FerrerBuitrago M, Claes E, Heindryckx B, De Vos WH, Nelis H et al. 2015 a Procaine induces cytokinesis in horse oocytes via a $\mathrm{pH}$ dependent mechanism. Biology of Reproduction 93 23. (doi:10.1095/biolreprod. 114.127423)

Leemans B, Gadella BM, Stout TA, Nelis H, Hoogewijs M \& Van Soom A $2015 b$ An alkaline follicular fluid fraction induces capacitation and limited release of oviduct epithelium-bound stallion sperm. Reproduction 150 193-208. (doi:10.1530/REP-15-0178)

Leemans B, Gadella BM, Stout TA, Sostaric E, Schauwer CD, Nelis H, Hoogewijs M \& Van Soom A 2016 Combined albumin and bicarbonate induces head-to-head sperm agglutination which physically prevents 
equine sperm-oviduct binding. Reproduction 151 313-330. (doi:10.1530/REP-15-0471)

Leese HJ 1988 The formation and function of oviduct fluid. Journal of Reproduction and Fertility 82 843-856. (doi:10.1530/jrf.0.0820843)

Lefebvre R, DeMott R, Suarez S \& Samper J 1995 Specific inhibition of equine sperm binding to oviductal epithelium. In Equine Reproduction VI, Biology of Reproduction Monograph 1 689-696.

Lefebvre R \& Samper J 1993 Interaction between stallion spermatozoa and oviductal epithelial cells in vitro. Equine Veterinary Journal 25 39-41. (doi:10.1111/j.2042-3306.1993.tb04822.x)

Levine N \& Marsh DJ 1971 Micropuncture studies of the electrochemical aspects of fluid and electrolyte transport in individual seminiferous tubules, the epididymis and the vas deferens in rats. Journal of Physiology 213 557-570. (doi:10.1113/jphysiol.1971.sp009400)

Li LY, Meintjes M, Graff KJ, Paul JB, Denniston RS \& Godke RA 1995 In vitro fertilization and development of in vitro-matured oocytes aspirated from pregnant mares. Biology of Reproduction Monograph 1 309-317.

Li XH, Morris LHA \& Allen WR 2001 Influence of co-culture during maturation on the developmental potential of equine oocytes fertilized by intracytoplasmic sperm injection (ICSI). Reproduction 121 925-932. (doi:10.1530/rep.0.1210925)

Lindahl PE \& Sjoblom P 1981 On mechanisms of head-to-head association in bovine spermatozoa. Biology of Reproduction 25 29-43. (doi:10.1095/ biolreprod25.1.29)

Lishko PV, Botchkina IL \& Kirichok Y 2011 Progesterone activates the principal Ca2+ channel of human sperm. Nature 471 387-391. (doi:10.1038/nature09767)

Lishko PV, Kirichok Y, Ren D, Navarro B, Chung JJ \& Clapham DE 2012 The control of male fertility by spermatozoan ion channels. Annual Review of Physiology 74 453-475. (doi:10.1146/annurev-physiol-020911-153258)

Liu Y, Wang DK \& Chen LM 2012 The physiology of bicarbonate transporters in mammalian reproduction. Biology of Reproduction $\mathbf{8 6}$ 99. (doi:10.1095/biolreprod.111.096826)

Maas D, Storey B \& Mastroianni L Jr 1977 Hydrogen ion and carbon dioxide content of the oviductal fluid of the rhesus monkey (Macaca mulatta). Fertility and Sterility 28 981-985. (doi:10.1016/S00150282(16)42801-3)

Malayer JR, Hansen PJ \& Buhi WC 1988 Secretion of proteins by cultured bovine oviducts collected from estrus through early diestrus. Journal of Experimental Zoology 248 345-353. (doi:10.1002/jez.1402480313)

McCue PM, Fleury J, Denniston DJ, Graham JK \& Squires EL 2000 Oviductal insemination of mares. Journal of Reproduction and Fertility Supplement 499-502.

McDowell KJ, Adams MH \& Williams NM 1993 Characterization of equine oviductal proteins synthesized and released at estrus and at day 4 after ovulation in bred and nonbred mares. Journal of Experimental Zoology 267 217-224. (doi:10.1002/jez.1402670215)

McPartlin LA, Suarez SS, Czaya CA, Hinrichs K \& Bedford-Guaus SJ 2009 Hyperactivation of stallion sperm is required for successful in vitro fertilization of equine oocytes. Biology of Reproduction 81 199-206. (doi:10.1095/biolreprod.108.074880)

Mugnier S, Kervella M, Douet C, Canepa S, Pascal G, Deleuze S, Duchamp G, Monget P \& Goudet G 2009a The secretions of oviduct epithelial cells increase the equine in vitro fertilization rate: are osteopontin, atrial natriuretic peptide $\mathrm{A}$ and oviductin involved? Reproductive Biology and Endocrinology 7 129. (doi:10.1186/14777827-7-129)

Mugnier S, Dell'Aquila ME, Pelaez J, Douet C, Ambruosi B, De Santis T, Lacalandra GM, Lebos C, Sizaret PY, Delaleu B, Monget P, Mermillod P et al. $2009 \mathrm{~b} \mathrm{New}$ insights into the mechanisms of fertilization: comparison of the fertilization steps, composition, and structure of the zona pellucida between horses and pigs. Biology of Reproduction $\mathbf{8 1}$ 856-870.

Murdoch RN \& White IG 1968 The influence of the female genital tract on the metabolism of rabbit spermatozoa. II. Effect of storage with glucose, lactate, bicarbonate, and female genital tract fluids. Australian Journal of Biological Sciences 21 973-980. (doi:10.1071/BI9680973)

Murray MK 1993 An estrogen-dependent glycoprotein is synthesized and released from the oviduct in a temporal- and region-specific manner during early pregnancy in the ewe. Biology of Reproduction $\mathbf{4 8}$ 446-453. (doi:10.1095/biolreprod48.3.446)

Nelis H, D'Herde K, Goossens K, Vandenberghe L, Leemans B, Forier K, Smits K, Braeckmans K, Peelman L \& Van Soom A 2014 Equine oviduct explant culture: a basic model to decipher embryo-maternal communication. Reproduction, Fertility and Development 26 954-966. (doi:10.1071/RD13089)

Palmer E, Bezard J, Magistrini M \& Duchamp G 1991 In vitro fertilization in the horse. A retrospective study. Journal of Reproduction and Fertility Supplement 44 375-384.

Pastor-Soler N, Pietrement C \& Breton S 2005 Role of acid/base transporters in the male reproductive tract and potential consequences of their malfunction. Physiology 20 417-428. (doi:10.1152/physiol.00036.2005)

Perry G 20132012 statistics of embryo collection and transfer in domestic farm animals. Embryo Transfer Newsletter 31 1-67.

Petrunkina AM, Gehlhaar R, Drommer W, Waberski D \& Topfer-Petersen E 2001 Selective sperm binding to pig oviductal epithelium in vitro. Reproduction 121 889-896. (doi:10.1530/rep.0.1210889)

Pollard JW, Plante C, King WA, Hansen PJ, Betteridge KJ \& Suarez SS 1991 Fertilizing-capacity of bovine sperm may be maintained by binding to oviductal epithelial-cells. Biology of Reproduction 44 102-107. (doi:10.1095/biolreprod44.1.102)

Publicover S, Harper CV \& Barratt C 2007 [Ca2+]i signalling in sperm making the most of what you've got. Nature Cell Biology 9 235-242. (doi:10.1038/ncb0307-235)

Rathi R, Colenbrander B, Stout TA, Bevers MM \& Gadella BM 2003 Progesterone induces acrosome reaction in stallion spermatozoa via a protein tyrosine kinase dependent pathway. Molecular Reproduction and Development 64 120-128. (doi:10.1002/mrd.10216)

Reischl J, Prelle K, Schol H, Neumuller C, Einspanier R, Sinowatz F \& Wolf E 1999 Factors affecting proliferation and dedifferentiation of primary bovine oviduct epithelial cells in vitro. Cell and Tissue Research 296 371-383. (doi:10.1007/s004410051297)

Roasa LM, Choi YH, Love CC, Romo S, Varner DD \& Hinrichs K 2007 Ejaculate and type of freezing extender affect rates of fertilization of horse oocytes in vitro. Theriogenology 68 560-566.

Rodriguez-Martinez H, Ekstedt E \& Einarsson S 1990 Acidification of epididymal fluid in the boar. International Journal of Andrology $\mathbf{1 3}$ 238-243. (doi:10.1111/j.1365-2605.1990.tb00982.x)

Rottmayer R, Ulbrich SE, Kolle S, Prelle K, Neumueller C, Sinowatz F, Meyer HHD, Wolf E \& Hiendleder S 2006 A bovine oviduct epithelial cell suspension culture system suitable for studying embryo-maternal interactions: morphological and functional characterization. Reproduction 132 637-648. (doi:10.1530/rep.1.01136)

Sabeur K \& Ball BA 2007 Characterization of galactose-binding proteins in equine testis and spermatozoa. Animal Reproduction Science 101 74-84. (doi:10.1016/j.anireprosci.2006.08.028)

Scott M, Liu I \& Overstreet J 1995 Sperm transport to the oviducts: abnormalities and their clinical implications. Proceedings of the American Association of Equine Practice 41 1-2.

Smith TT \& Nothnick WB 1997 Role of direct contact between spermatozoa and oviductal epithelial cells in maintaining rabbit sperm viability. Biology of Reproduction 56 83-89. (doi:10.1095/biolreprod56.1.83)

Smith TT \& Yanagimachi R 1991 Attachment and release of spermatozoa from the caudal isthmus of the hamster oviduct. Journal of Reproduction and Fertility 91 567-573. (doi:10.1530/jrf.0.0910567)

Sostaric E, Dieleman SJ, van de Lest CH, Colenbrander B, Vos PL, GarciaGil N \& Gadella BM 2008 Sperm binding properties and secretory activity of the bovine oviduct immediately before and after ovulation. Molecular Reproduction and Development 75 60-74. (doi:10.1002/ mrd.20766)

Sostaric E, van de Lest CH, Colenbrander B \& Gadella BM 2005 Dynamics of carbohydrate affinities at the cell surface of capacitating bovine sperm cells. Biology of Reproduction 72 346-357. (doi:10.1095/ biolreprod.104.029330)

Steptoe PC \& Edwards RG 1978 Birth after the reimplantation of a human embryo. Lancet 312 366. (doi:10.1016/S0140-6736(78)92957-4)

Strunker T, Goodwin N, Brenker C, Kashikar ND, Weyand I, Seifert R \& Kaupp UB 2011 The CatSper channel mediates progesterone-induced $\mathrm{Ca} 2+$ influx in human sperm. Nature 471 382-386. (doi:10.1038/ nature09769)

Suarez SS 2001 Carbohydrate-mediated formation of the oviductal sperm reservoir in mammals. Cells, Tissues and Organs 168 105-112. (doi:10.1159/000016811)

Suarez SS 2002 Formation of a reservoir of sperm in the oviduct. Reproduction in Domestic Animals 37 140-143. (doi:10.1046/j.14390531.2002.00346.x) 
Suarez SS 2008 Regulation of sperm storage and movement in the mammalian oviduct. International Journal of Developmental Biology 52 455-462. (doi:10.1387/ijdb.072527ss)

Thibodeaux JK, Myers MW, Goodeaux LL, Menezo Y, Roussel JD, Broussard JR \& Godke RA 1992 Evaluating an in vitro culture system of bovine uterine and oviduct epithelial cells for subsequent embryo co-culture. Reproduction, Fertility and Development 4 573-583. (doi:10.1071/RD9920573)

Thomas PG, Ball BA \& Brinsko SP 1994a Interaction of equine spermatozoa with oviduct epithelial cell explants is affected by estrous cycle and anatomic origin of explant. Biology of Reproduction 51 222-228. (doi:10.1095/biolreprod51.2.222)

Thomas PG, Ball BA, Miller PG, Brinsko SP \& Southwood L 1994b A subpopulation of morphologically normal, motile spermatozoa attach to equine oviductal epithelial cell monolayers. Biology of Reproduction $\mathbf{5 1}$ 303-309. (doi:10.1095/biolreprod51.2.303)

Thomas PGA, Ball B \& Brinsko S 1995a Changes associated with induced capacitation influence the interaction between equine spermatozoa and oviduct epithelial cell monolayers. Biology of Reproduction Monograph 1 697-705

Thomas PGA, Ignotz GG, Ball BA, Miller PG, Brinsko SP \& Currie B 1995b Isolation, cultureand characterization of equine oviduct epithelialcells in-vitro. Molecular Reproduction and Development 41 468-478. (doi:10.1002/mrd.1080410409)

Topfer-Petersen E, Ekhlasi-Hundrieser M, Kirchhoff C, Leeb T \& Sieme H 2005 The role of stallion seminal proteins in fertilisation. Animal Reproduction Science 89 159-170. (doi:10.1016/j. anireprosci.2005.06.018)

Tremoleda JL, Gadella BM, Stout TAE, Colenbrander B \& Bevers MM 2003 Evaluation of sperm-oocyte interaction during in vitro fertilization in the horse. In In Vitro Production of Horse Embryos: Fundamental Aspects, pp 67-91. Tremoleda JL (2003): Dissertation Utrecht University, Faculty of Veterinary medicine.

Vishwakarma P 1962 The $\mathrm{pH}$ and bicarbonate-ion content of the oviduct and uterine fluids. Fertility and Sterility 13 481-485. (doi:10.1016/ S0015-0282(16)34633-7)

Walter I 1995 Culture of bovine oviduct epithelial-cells (Boec). Anatomical Record Colenbrand 347-356. (doi:10.1002/ar.1092430309)

Winger QA, delosRios P, Han VKM, Armstrong DT, Hill DJ \& Watson AJ 1997 Bovine oviductal and embryonic insulin-like growth factor binding proteins: possible regulators of 'embryotrophic' insulin-like growth factor circuits. Biology of Reproduction 56 1415-1423. (doi:10.1095/ biolreprod56.6.1415)

Yanagimachi R 1969 In vitro capacitation of hamster spermatozoa by follicular fluid. Journal of Reproduction and Fertility 18 275-286. (doi:10.1530/jrf.0.0180275)

Yao Y, Ho P \& Yeung WS 2000 Effects of human follicular fluid on the capacitation and motility of human spermatozoa. Fertility and Sterility 73 680-686. (doi:10.1016/S0015-0282(99)00637-8)

Zhang JJ, Muzs LZ \& Boyle MS 1990 In vitro fertilization of horse follicular oocytes matured in vitro. Molecular Reproduction and Development 26 361-365.

Received 1 August 2016

First decision 13 September 2016

Accepted 15 September 2016 